\title{
Ekspansi Perkebunan Kelapa Sawit : Persoalan Sosial, Ekonomi dan Lingkungan Hidup (Studi Kasus Kab. Pelalawan, Riau)
}

\author{
Suryadi ${ }^{1}$, Arya Hadi Dharmawan², dan Baba Barus² \\ 1Fakultas pertanian Universitas Musamus ; e-mail: Suryamerauke@gmail.com \\ ${ }^{2}$ Sekolah Pasca Sarjana IPB University
}

\begin{abstract}
ABSTRAK
Perkebunan kelapa sawit berdampak positif dan negatif pada aspek-aspek lingkungan, sosial dan ekonomi komunitas lokal. Melalui pemahaman tentang data kondisi lingkungan, sosial dan ekonomi memudahkan pengambil keputusan dalam kebijakan. Penelitian ini menggunakan metode survey dan wawancara mendalam (sebutkan jumlah responden, guideline wawancara mendalam sebutkan), penelitian ini bertujuan untuk mengukur tingkat kerentanan ekonomi, sosial dan ekologi akibat ekspansi perkebunan kelapa sawit. Data yang digunakan adalah data primer dan data sekunder. Pengumpulan data primer melalui observasi dan wawancara terstruktur dan mendalam. Data sekunder yang diperoleh dari kantor desa, instansi pemerintahan terkait, BPS, buku, jurnal, atau data dari internet yang memuat teori atau hasil penelitian yang terkait. Hasil penelitian ini menjelaskan bahwa ekspansi kelapa sawit yang terjadi di Desa terantang Manuk melalui pola pola PIR-Trans, KKPA, PKS tanpa kebun, jual beli, hibah, dan swadaya atau mandiri. Dampak lingkungan yang ditimbulkan oleh ekspansi kelapa sawit yaitu menurunkan kerangaman buah, ikan, sayur, dan hewan buruan serta penurunan kuantitas air tanah terutama pada saat musim kemarau. Dampak ekonomi akibat ekspansi perkebunan sawit yaitu semakin terlihatnya gab ekonomi antara kelas atas, menengah dan bawah. Sedangkan dampak sosial yang ditimbulkan adalah berubahnya norma-norma adat, adanya praktek rent seeking serta munculnya konflik-konflik baru.
\end{abstract}

Kata kunci: Kelapa sawit, Ekonomi, Sosial, Lingkugan

\begin{abstract}
Oil palm plantations have positive and negative impacts on the environmental, social and economic aspects of local communities. Through an understanding of the data on environmental, social and economic conditions makes it easier for decision makers in policy. This research uses survey methods and in-depth interviews (state the number of respondents, state in-depth interviews). This study aims to measure the level of economic, social and ecological vulnerability due to oil palm plantations. The data used are primary data and secondary data. Primary data collection through structured and in-depth observation and interviews. Secondary data is obtained from the village office, related government agencies, BPS, books, journals, or data from the internet which contains theories or related research results. The results of this study explain that oil palm expansion that occurs in Terantang Manuk Village is through the PIR-Trans pattern, KKPA, PKS without plantation, buying and selling, grants, and self-help or independent. The environmental impact caused by oil palm expansion is reducing fruit, fish, vegetable and game shellfish and decreasing the quantity of groundwater, especially during the dry season. The economic impact due to the expansion of oil palm plantations has seen an increasingly unified economy between the upper, middle and lower classes. Meanwhile, the resulting social impact is the change in customary norms, the practice of leasing and new conflicts.
\end{abstract}

Keywords: Oil palm, Economy, Social, Environment

Citation: Suryadi, Dharmawan, A.H., dan Barus,B. (2020). Ekspasi Perkebunan Kelapa Sawit: Persoalan Sosial, Ekonomi dan Ekologi (Studi Kasus Desa Terantang Manuk). Jurnal Ilmu Lingkungan, 18(2), 367-374, doi:10.14710/Jil.18.2.367-374

\section{Latar Belakang}

Tanaman kelapa sawit didatangkan pertama kali di Indonesia pada tahun 1848 oleh pemerinta Hindia Belanda. Beberapa bijinya ditanam di Kebun Raya Bogor, sementara sisa benihnya ditanam di tepi-tepi jalan sebagai tanaman hias di Deli, Sumatera Utara pada tahun 1870-an kemudian tahun 1911 oleh warga negara Belgia yaitu Adrien Hallet dan K Schadt dengan cara menanamnya secara komersial di Sumatera Utara (Dewanto 2013). Kemudian pada tahun 1980 terjadi perkembangan dan perluasan perkebunan kelapa sawit di Indonesia.

Provinsi Riau merupakan wilayah yang memiliki pertanaman kelapa sawit terluas di Indonesia, pada tahun 2018 luas perkebunan kelapa sawit di provinsi ini mencapai 2.706.892 ha dengan produksi 8.496.029 ton atau $19,81 \%$ dari kontribusi CPO Nasional. Ekspansi perkebunan kelapa sawit dimulai sejak tahun 1984 dan areal perkebunan kelapa sawit sebagian besar dimiliki oleh perkebunan Korporasi 
yaitu 49,81\% dan perkebunan rakyat 45,54\% (Direktorat Jenderal Perkebunan, 2020).

Permintaan lahan untuk ekspansi perkebunan sawit di Provinsi Riau terus meningkat sehingga telah memicu tingginya angka konversi lahan atau hutan menjadi perkebunan kelapa sawit. (Barus, et al. 2012) menyatakan bahwa diseluruh sumatra luasan kelapa sawit didaerah gambut sekitar 1,5 juta hektar, sedangkan dilahan kering sekitar 3,2 juta hektar. Daerah kelapa sawit terbesar digambut berada di Propinsi Riau, menyusul Sumatra Selatan dan Sumatra Utara. Sedangkan penyebaran sawit dilahan kering 36 terbesar juga terdapat di tiga propinsi tersebut dengan urutan Propinsi Riau, menyusul Sumatra Utara dan ketiga Sumatra Selatan.

Ekspansi kelapa sawit juga memberikan dampak terhadap menurunnya keanekaragaman hayati di suatu landskap. Didalam pedoman ISPO pelestarian keanekaragaman hayati merupakan salah satu prinsip dan kriteria dalam menentukan keberlanjutan usaha perkebunan kelapa sawit dengan memiliki 2 indikator yaitu (1) Pekebun, kelompok tani, koperasi harus mengetahui keberadaan satwa dan tumbuhan di area tersebut dan di sekitar kebun, sebelum dan sesudah dimulainya usaha perkebunan, (2) Tersedia catatan satwa dan tumbuhan di kebun dan sekitar kebun.

Ekspansi perkebunan kelapa sawit menjadikan rumahtangga petani melakukan transformasi nafkah yaitu dari berladang berpindah subsisten menjadi berladang berpindah komersial dengan cara menanami tanaman kelapa sawit. Serta adanya peristiwa pelepasan lahan oleh sebagian petani akibat aktivitas jual beli tanah dan pembebasan lahan. Sementara itu, berkembangnya usaha dan pekerjaan di luar usaha tani kelapa sawit pada dasarnya mampu memperbaiki ketidakmerataan yang ada akan tetapi belum mengubah distribusi pendapatan menjadi merata (Widiono, 2008). Pada dasarnya masyarakat petani di sekitar hutan merupakan masyarakat yang tergantung pada sumberdaya hutan. Adanya perubahan hutan menjadi perkebunan kelapa sawit ini mengakibatkan perubahan relung nafkah sehingga berdampak pada struktur nafkah rumahtangga petani.

Pengelolaan perkebunan sawit yang jauh dari upaya mensejahterakan masyarakat justru melahirkan konflik terbuka untuk perebutan lahan (Thomas et al., 2015), sedangkan konflik tenurial merupakan konflik yang sering terjadi pada perkebunan kelapa sawit (Mantiri, 2013), (Sumardjo et al., 2014), (Sadewo et al., 2014), (Wulansari, 2017), (Dhiaulhaq et al., 2018), (Riady \& Bakce, 2019). Ekspansi perkebunan kelapa sawit berdampak pada tingginya frekuensi konflik sosial khususnya konflik antar petani dan petani dengan perusahaan perkebunan kelapa sawit (Amalia, R. dkk 2019), sedangkan (Konsorsium Pembaruan Agraria. 2019) menyatakan bahwa dari 144 ledakan konflik agraria yang terjadi di sektor perkebunan sepanjang tahun 2018, sebanyak 83 kasus atau $60 \%$-nya terjadi di perkebunan komoditas kelapa sawit.

Berdasarkan hal tersebut maka tujuan dari penelitian ini yaitu:

1. Menanalisis persoalan lingkungan akibat ekspansi perkebunan kelapa sawit.

2. Menganalisis persoalan ekonomi akibatekspansi perkebunan kepala sawit

3. Menganalisis persoalan sosial akibat ekspansi perkebunan kelapa sawit

\section{Metode Penelitian}

Penelitian ini menggunakan studi kasus (Creswell \& Poth, 2018). Studi kasus ini difokuskan pada masalah tertentu, yaitu ekspansi perkebunan: persoalan sosial, ekonomi dan lingkungan di Desa Terantang Manuk. Strategi penelitian ini menggunakan mixed method dengan cara menggabungkan metode penelitian kuantitatif dengan metode penelitian kualitatif.

Penelitian ini dilakukan pada Desember tahun 2017 hingga Januari 2019 yang berada pada jalan raya trans Sumatera KM.95, Kecamatan Pangkalan Kuras, Kabupaten Pelalawan, Provinsi Riau. Desa Terantang Manuk memiliki tiga dusun dimana Dusun I dan Dusun II yang merupakan wilayah induk berada di jalur jalan Trans Sumantera, sedangkan Dusun III (Pangkalan Papan) terletak di wilayah terpisah (enclave). Luas Desa Terantang Manuk 5.715 hektar dengan 765 keluarga dengan jumlah penduduk sebanyak 2.486 jiwa pada tahun 2017 dengan 711 keluarga atau 93\% keluarga merupakan petani (Badan Pusat Statistik 2018).

Data yang digunakan adalah data primer dan data sekunder. Pengumpulan data primer melalui observasi dan wawancara terstruktur dan mendalam. Sedangkan untuk data sekunder bersumber dari dokumen privat, surat, putusan pengadilan, dan informasi dari media massa yang berkaitan dengan penelitian.

\section{Persoalan Lingkungan \\ 3.1. Pola Ekspansi}

Pola pengusahaan kelapa sawit rakyat di Desa Terantang Manuk beragam. Ada yang swadaya dan ada juga yang kemitraan. Ekspansi kelapa sawit berlangsung melalui berbagai pola, yaitu pola PIRTrans, KKPA, PKS tanpa kebun, jual beli, hibah, dan swadaya atau mandiri.

Tabel 1 menjelaskan bahwa perkebunan sawit di desa terantang manuk 83\% dikuasai oleh koporasi dan $17 \%$ dikuasai oleh masyarakat. Ekspansi perkebunan kelapa sawit yang terjadi tidak hanya disebabkan karena otoritas legal-formal milik pemerintah namun juga otoritas kultural-lokal milik tokoh masyarakat yang keduanya dapat terjadi secara bersama-sama. 
Tabel 1. Pola ekspansi dan aktor yang terlibat

\begin{tabular}{|c|c|c|c|}
\hline Pola Ekspansi & Tahun & $\begin{array}{l}\text { Luas Lahan } \\
\text { Perkebunan }\end{array}$ & Aktor Yang Terlibat dan Peranannya \\
\hline PIR-Trans & $1989-2019$ & 1708, 8 ha & Pemerintah (regulator), perusahaan (inti), petani (plasma) \\
\hline KKPA & $2006-2019$ & $1.464,9$ ha & $\begin{array}{l}\text { Pemerintah (regulator), perusahaan (inti), petani (plasma), koperasi } \\
\text { (KKPA) }\end{array}$ \\
\hline PKS tanpa kebun & 2008-2019 & 0 ha & Pemerintah (regulator), perusahaan (PKS), kopersi (mitra) \\
\hline Jual beli & $2010-2019$ & 88 ha & $\begin{array}{l}\text { Calo tanah, Masyarakat luar daerah dari Medan, Bekasi dan Bandung } \\
\text { (pembeli) }\end{array}$ \\
\hline Hibah & $2006-2019$ & 120 ha & Tetua Adat (penghibah), masyarakat transmigran (petani) \\
\hline Mandiri & 1996-2019 & 438,2 ha & Masyarakat (petani) \\
\hline
\end{tabular}

PIR-Trans adalah pola pelaksanaan, pengembangan perkebunan dengan menggunakan perkebunan besar sebagai inti yang membantu dan membimbing perkebunan rakyat di sekitarnya sebagai plasma dalam suatu sistem kerjasama yang saling menguntungkan, utuh, dan berkesinambungan (Instruksi Presiden Republik Indonesia, 1986).

Kredit kepada Koperasi Primer untuk Anggotanya (KKPA) merupakan pola kemitraan perusahaan inti dan plasma dalam wadah koperasi untuk meningkatkan daya guna lahan petani peserta dalam usaha meningkatkan pendapatan dan kesejahteraan para anggota melalui kredit jangka panjang dari bank.

Pabrik Kelapa Sawit (PKS) tanpa kebun merupakan pabrik kelapa sawit yang tidak memiliki lahan atau perkebunan kelapa sawit, PKS tanpa kebun biasanya mendapat pasokan tandan buah segar (TBS) dari masyarakat yang berbentuk koperasi maupun individu.

Ekspansi perkebunan kelapa sawit melalui pola hibah di Desa Terantang Manuk terjadi di Dusun III
(Enclave Pangkalan Papan). Lahan di wilayah ini merupakan tanah adat Ulayat Batin Pematan.

Ekspansi perkebunan kelapa sawit di Terantang Manuk juga terjadi melalui jual beli lahan. Para pembeli yang merupakan pemilik modal berasal dari luar desa. Mereka membeli lahan dengan cara komunal.

Ekspansi perkebunan kelapa sawit dengan pola mandiri atau swadaya dilakukan oleh masyarakat lokal Terantang Manuk dalam periode 2000-2009 setelah melihat keberhasilan transmigrasi membudidayakan kelapa sawit.

\subsection{Perubahan tutupan lahan}

Dalam penelitian ini metode pengolahan peta tutupan lahan menggunakan software Arc-GIS melalui digitasi on screen dan intepretasi visual pada Citra Google Earth tahun 2019 lalu di overlay dengan Peta Rupabumi Indonesia (RBI), peta hak guna usaha (HGU) dan Non HGU serta Peta letak Pabrik kelapa Sawit. Klasifikasi penutupan lahan menggunakan (SNI 7645-1 2014).

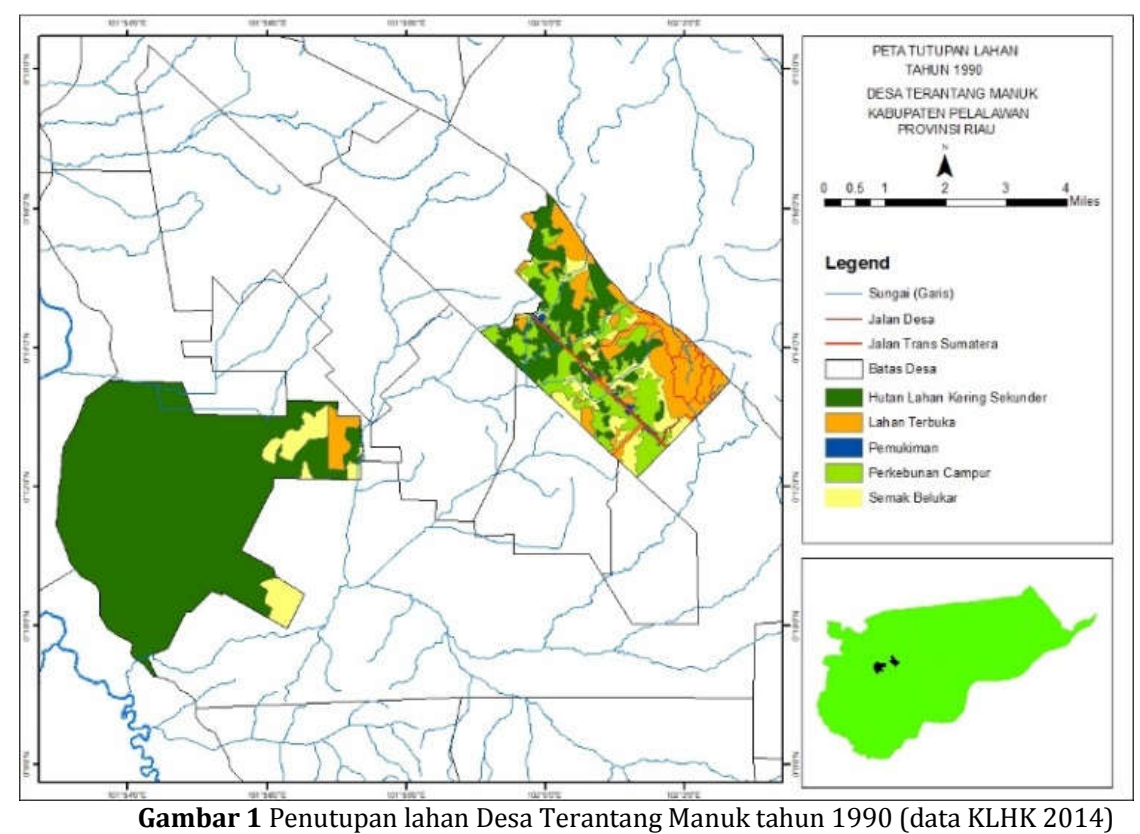

Tutupan lahan desa terantang manuk pada tahun 1990 didominasi dengan tutupan lahan berupa hutan dan semak belukar, dimana dusun 1 dan 2 didominasi oleh semak belukar, hutan tanaman dan pemukiman, dimana dusun 1 dan 2 merupakan pusat pemukiman dan pemerintahan Desa, sedangakan Dusun 3 (enclave) berupa hutan yang merupakan bekas perkampungan lama. 


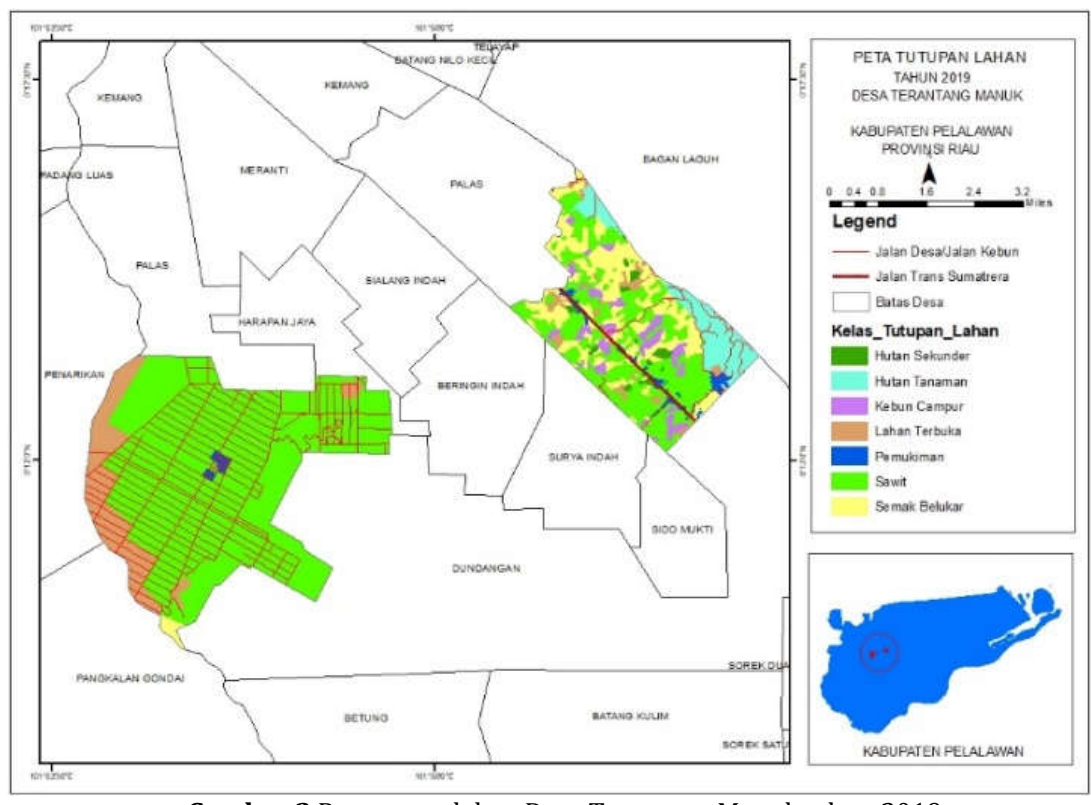

Gambar 2 Penutupan lahan Desa Terantang Manuk tahun 2019

Gambar 2 menunjukkan penutupan lahan desa Terantang manuk setelah ekspansi perkebunan kelapa sawit selama 29 tahun, dimana sawit mendominasi tutupan lahan di desa terantang manuk dan telah terjadi deforestasi di desa terantang manuk yang berdampak pada turunnya kuantitas komponon ekologi (tabel 4).

Tabel 2. Luasan kelas tutupan lahan tahun 2019

\begin{tabular}{lcc}
\hline \multirow{2}{*}{ Tutupan Lahan } & \multicolumn{2}{c}{ Luas (Ha) } \\
\cline { 2 - 3 } & 1990 & 2019 \\
\hline Hutan & 3250 & 45,14 \\
Kebun Campur & 262,9 & 164,1 \\
Lahan Terbuka & 133 & 572 \\
Pemukiman & 76 & 108,9 \\
Sawit & - & 3912,9 \\
Semak Belukar & 1785 & 628,5 \\
HTI & 208 & 283,45 \\
\hline
\end{tabular}

Sumber data diolah dari penutupan lahan KEMNHUT 2014 dan hasil interpretasi manual pada citra google eart.

Tabel 1 menjelaskan bahwa 68\% tutupan lahan Desa Terantang Manuk berupa perkebunan sawit dengan laju ekspansi 134,9 ha/tahun. Tutupan lahan berupa hutan juga mengalami deforestasi dimana pada hutan yang sebesar 62\% pada tahun 1990 menurun menjadi 1\% yang berupa areal pelestarian pohon sialang yang merupakan sarang lebah penghasil madu sialang.

\section{3. ketersediaan air}

Meskipun belum ada kajian ilmiah mengenai berapa penurunan debit air masyarakat telah merasakan dampaknya penurunan debit air terutama dalam musim kemarau di Desa Terantang Manuk. Persepsi masyarakat terhadap ketersediaan air akibat ekspansi perkebunanan mempunyai pengaruh yang cukup tinggi dimana 93\% masyarakat dari 30 responden rumah tangga pernah mengalami krisis air bersih dan mengalami penurunan kuantitas air dan ketinggian muka air tanah, masyarakat menyatakan air sumur mereka harus digali lebih dalam, di mana sumur-sumur harus digali pada kedalaman di atas 7 m. Pernyataan ini sejalan dengan (FWI 2007) dalam (Yani 2011) akibat ekspansi perkebunan kelapa sawit yang dilakukan melalui konversi hutan alam, akan merusak habitat hutan, dan merubah lanskap hutan alam, selain itu akan merusak kondisi daerah aliran sungai (DAS) yang berada di bawahnya. Sedangkan 7\% masyarakat mengatakan bahwa kuantitas air dan ketinggian muka air tanah tidak berubah, hal ini dikarenakan sumur masyarakat yang tidak terdampak penurunan kuantitas dan ketinggian muka air tanah terletak di kantung-kantung air yang berada di dataran rendah atau lembah yang berada di desa Terantang Manuk. Perubahan yang paling dirasakan adalah ketahanan air, dimana 100\% masyarakat mengatakan pada musim kemarau air sumur lebih cepat mongering dibandingkan dulu sebelum ekspansi sawit.

\subsection{Keanekaragaman Hayati}

Hasil persepsi masyarakat mengenai dampak ekspansi terhadap kondisi lingkungan disajikan pada tabel 4. Ruang lingkup keragaman jenis buah, sayur, ikan dan hewan buruan dalam penelitian ini hanya sebatas wilayah desa atau tidak menginterpretasi keadaan daerah lainnnya.

Tabel 3. Persepsi Masyarakat Terhadap Populasi Keanekaragaman Hayati

\begin{tabular}{lcccc}
\hline \hline & \multicolumn{4}{c}{ Keragaman (jenis) } \\
\cline { 2 - 5 } & Punah & Menurun & Tetap & Meningkat \\
\hline Buah & 25 & 20 & 2 & 0 \\
Sayur & 4 & 18 & 12 & 1 \\
Ikan & 13 & 1 & 54 & 0 \\
Hewan & 9 & 9 & 3 & 2 \\
Buruan & & & & \\
\hline
\end{tabular}

Persepsi masyarakat terhadap dampak dari ekspansi dapat dilihat dari perubahan kondisi lingkungan yang terjadi, dari total responden 
masyarakat sebanyak 30 responden terhadap ketersediaan ikan dari 68 jenis ikan 79\% populasi ikan tetap, 19\% pupulasi ikan menurun dan 2\% populasi ikan punah. Ketersediaan buah lokal, dari 47 jenis buah $53 \%$ jenis buah punah, $43 \%$ jenis buah menurun dan $4 \%$ jenis buah tetap. Ketersediaan sayur dan bumbu lokal, dari 35 jenis sayur dan bumbu lokal $52 \%$ jenis sayur lokal menurun, $34 \%$ jenis sayur lokal tetap, dan $11 \%$ jenis sayur lokal punah dan $3 \%$ jenis sayur lokal meningkat, sedangkan dari 23 jenis hewan buruan 39\% jenis hewan buruan punah, 39\% jenis hewan buruan menurun, dan $13 \%$ jenis hewan buruan tetap dan $9 \%$ hewan buruan meningkat.

\section{Persoalan Ekonomi}

\subsection{Struktur Pendapatan}

Struktur nafkah adalah komposisi pendapatan rumah tangga petani dari berbagai aktivitas nafkah yang dilakukan oleh seluruh anggota rumah tangga dalam kurun waktu satu tahun.

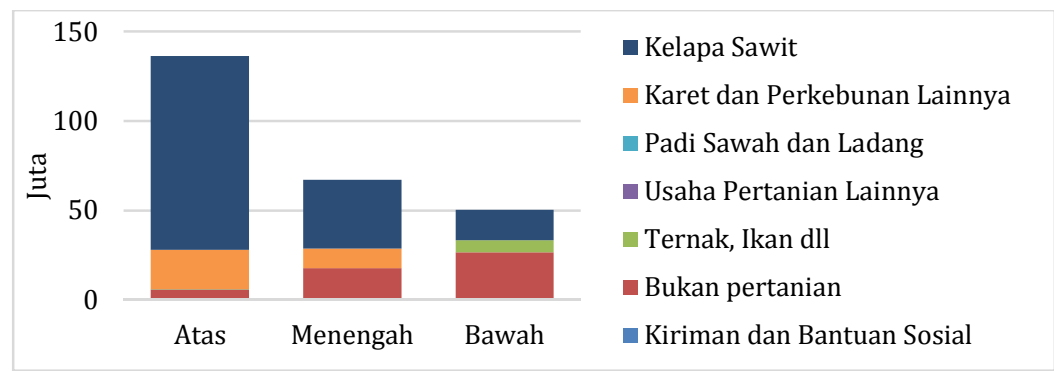

Gambar 3 Struktur Nafkah Rumah Tangga Petani Perlapisan (RP/Tahun)

Dari 30 responden rumahtangga menunjukkan bahwa pendapatan yang paling tinggi berasal dari perkebunan sawit dimana menyumbang $64 \%$ dari total pendapatan, bukan pertanian $20 \%$, ternak, ikan dan dll 13\%, dan karet dan tanaman perkebunan lainnya $3 \%$.

Sumber pendapatan rumah tangga pekebun kelapa sawit swadaya lapisan menengah dan lapisan atas di Desa Terantang Manuk didominasi oleh usaha sektor perkebunan kelapa sawit berkisar $57,1 \%$ dari total pendapatan untuk golongan menengah dan $78,3 \%$ golongan atas, sedangkan rumahtangga pekebun kelapa lapisan bawah di desa ini lebih banyak berasal dari usaha di sektor bukan pertanian atau sekitar $52,8 \%$.

\subsection{Struktur pengeluaran}

Tingginya tingkat ketergantungan masyarakat desa terhadap sawit bisa terlihat dari pola konsumsi masyarakat. Kebutuhan pangan masyarakat tidak lagi diperoleh dari dalam desa melainkan di datangkan dari luar desa. Artinya masyarakat desa tidak lagi mandiri dalam penyediaan pangan.

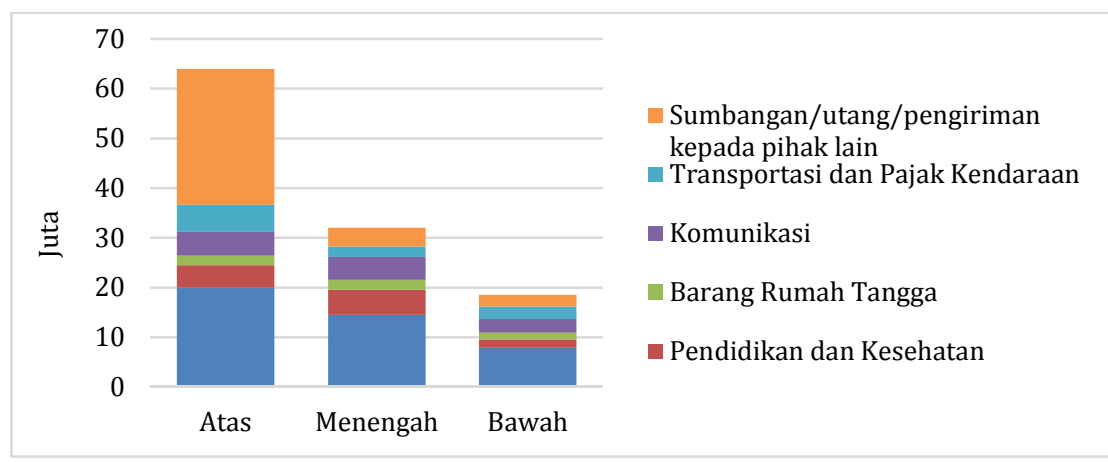

Gambar 4. Struktur pengeluaran Rumah Tangga Petani Perlapisan (RP/Tahun)

Dari 30 responden rumahtangga petani menunjukkn bahwa pengeluaran paling yang dikeluarkan kalangan atas adalah utang, sumbangan atau pengiriman kepada pihak lain, sedangkan kelas menengah dan bawah pengeluaran terbesar adalah untuk kebutuhan pangan.

Pengeluaran rata-rata rumah tangga responden Desa Terantang Manuk adalah 33,1 juta/tahun atau 2,7 juta/bulan jika dibandingkan dengan besarnya pendapatan yang mereka terima $85,7 \mathrm{juta} / \mathrm{tahun}$ atau 7,1 juta/bulan, hal ini memperlihatkan bahwa aktifitas ekonomi petani sawit di Desa Terantang Manuk surplus.

\subsection{Kemampuan Menyimpan}

Kemampuan menyimpan (Saving Capacity) merupakan kemampuan yang dimiliki oleh rumah tangga untuk dapat menabung atau menyimpan uangnya. Kemampuan menyimpan ini diukur melalui pendapatan yang diterima per tahun dikurangi dengan pengeluaran rumah tangga per tahun. Dari hasil tersebut, apabila hasil pengurangan tersebut besar maka tingkat kemampuan menyimpan yang dimiliki oleh keluarga tersebut tinggi namun apabila hasilnya kecil atau minus maka tingkat kemampuan menyimpan yang dimiliki oleh keluarga tersebut rendah. 


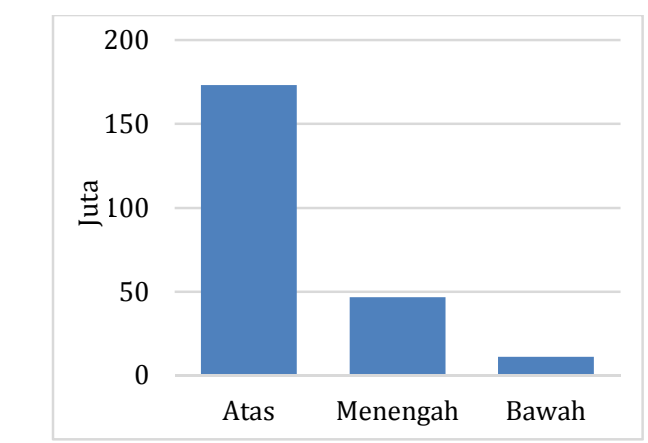

Gambar 5. Kemampuan menyimpan Rumah Tangga Petani Perlapisan (RP/Tahun)

Tingkat kemampuan menyimpan dilihat menurut lapisan masyarakat pada kedua desa. Terdapat delta pendapatan dikurangi pengeluaran maka untuk masyarakat lapisan atas Desa Terantang Manuk memiliki kemampuan menyimpan yang cukup tinggi sementara lapisan menengah dan bawah tingkat kemampuan menyimpannya rendah.

Untuk lapisan atas Desa Terantang Manuk mampu menyimpan rata rata pertahun sebesar $\mathrm{Rp}$ 173.295.875 pertahun. Angka ini cukup besar dibandingkan dengan dua lapisan dibawahnya. Lapisan menengah Desa Air Hitam masih memiliki saving capacity sebesar Rp 46.708 .894 pertahun. Sedangkan golongan bawah kedua desa ini hanya mampu menyimpan rata-rata Rp.11.271.213 per tahun.

\section{Persoalan Sosial}

\subsection{Perubahan Norma Berladang}

Dalam norma adat, jika ladang yang telah dibuka dan ditanami oleh salah satu masyarakat, maka masyarakat lain tidak boleh membuka di areal depan atau belakang lahan tersebut karena untuk mengantisipasi jika peladang tersebut akan menambah luasan ladang (kapalo ladang). Dalam norma adat ladang bekas yang sudah tidak diolah atau tidak ditanami lagi oleh masyarakat boleh diambil alih oleh masyarakat lain untuk tanami.

Sedangkan setelah ekspansi, bekas ladang yang sudah tidak ditanami oleh orang tua salah satu masyarakat tidak boleh lagi ditanami oleh masyarakat lain, hal ini dikarenakan sudah menipisnya sumberdaya lahan yang tersedia di desa. Perubahan norma berladang ini menimbulkan konflik lahan akibat perbedaan persepsi antara masyarakat yang masih memegang norma lama dan masyarakat yang tidak lagi memegang norma adat.

\subsection{Praktek Rent-Seeking}

Istilah rent seeking pertama kali diperkenalkan oleh Gordon Tullock pada tahun 1967. Melalui publikasinya berjudul The Welfare Cost of Tariffs, Monopolies, and Theft, Gordon Tullock menulis tentang hubungan pemberian hak monopoli kepada pengusaha oleh penguasa. Kemudian, berkembang dengan penjelasan bahwa pemburu rente adalah pengusaha yang mendapatkan lisensi khusus, monopoli, dan fasilitas lain dari penguasa sekaligus menghambat pelaku lain masuk pasar. Dari situ kemudian lahir teori perburuan rente (theory of economic rent-seeking) yang dipopulerkan oleh Anna Krueger di tahun 1974. Teori perburuan ekonomi rente menjelaskan fenomena perilaku pengusaha untuk mendapatkan monopoli pada suatu bidang tertentu dari pihak yang berkuasa. Sementara rente diartikan sebagai selisih antara nilai pasar dari suatu "kebaikan hati" birokrasi dengan jumlah yang dibayar oleh penerima rente kepada birokrasi/pemerintah atau kepada perorangan di birokrasi. Istilah "Rent Seeking" menurut Adam Smith (1981) membagi penghasilan (income) dalam tiga tipe, laba, upah dan sewa (profits, wages, and rents).

Kata rente di sini tidak sama dengan pengertian rente yang dijelaskan Adam Smith. Rente dalam pengertian Adam Smith adalah sewa yang berarti memperoleh keuntungan dari jasa sewa-menyewa. Sementara, pemburu rente dalam kajian ekonomi politik adalah perburuan untuk mendapatkan fasilitas lisensi, monopoli, ataupun cara-cara memperdagangkan kekuasaan untuk memperoleh keuntungan bisnis. Mereka mencari keuntungan bukan melalui persaingan yang sehat.

Michael Ross (2001) membagi rent seeking menjadi tiga tipe antara lain rent creation, rent extraction, dan rent seizing. Rent creation merujuk pada kondisi dimana perusahaan mencari keuntungan yang dibuat oleh negara dengan menyogok politisi dan birokrat. Rent extraction menggambarkan politisi dan birokrat mencari keuntungan dari perusahaan dengan mengancam perusahaan melalui regulasi. Sedangkan rent seizing terjadi ketika birokrat berusaha untuk mendapatkan hak mengalokasikan rente yang dihasilkan dari institusi negara untuk kepentingan individu/kelompok.

Praktek rent-seeking yang terjadi pada desa Terantang Manuk terdapat dua tipe yaitu Rent extraction dan rent seizing. Praktek rent seizing yang terjadi di Desa Terantang Manuk bukan dilakukan oleh politisi maupun birokrat tetapi dilakukan oleh kaum pemuda (kalangan akar rumput) yang pengetahuan dan pendidikan yang cukup tinggi dan memiliki pengaruh yang cukup besar dalam tatanan sosial masyarakat Desa Terantang Manuk, oknum pemuda menggunakan pelanggaran atau Tindakan perusahaan yang bertentang dengan peraturan atau regulasi untuk menekan perusahaan agar melakukan negosiasi. Tahapan kegiatan yang dilakukan oleh pencari rente ini adalah (1) identifikasi pelanggaran yang dilakukan pihak perusahaan, (2) riset tentang isu tersebut (3) menyebarkan isu tentang pelanggaran perusahaan kepada warga desa (4) jika isu tersebut tidak masih belum di tanggapi oleh pihak perusahaan maka aktor rent seeking akan menyebarkan isu tersebut melalui media elektronik lokal, (5) melakukan aksi demo dengan mengerahkan massa. (6) Pada saat pihak perusahaan telah tersudut akibat isu tersebut maka dalam upaya mengamankan posisi 
perusahaan aktor kunci dalam prakter rent seeking akan dilakukan pendekatan persuasif, salah satunya dengan proses negosiasi atau tawar menawar dengan aktor tersebut yang dapat menguntungkan kedua belah pihak. Upaya negosiasi dapat berupa tawar menawar pekerjaan (biasanya sebagai humas perusahaan), proyek yang terkait dengan kegiatan perusahaan, dana tunai, pemberian beasiswa dan lainnya.

Praktek Rent extraction dilakukan oleh oknum birokrat dilingkungan pemerintah daerah Kabupaten pelalawan dengan mengambil alih lahan hibah KKPA oleh masyarakat Desa Terantang Manuk untuk Pemerintah Kabupaten Pelalawan seluas 20 hektar, lahan hibah tersebut diterbitkan SKT atas nama keluaraga dari oknum birokrat tersebut, hal ini menyebabkan munculnya protes dan aksi demo dari keluarga baru yang tidak mendapatkan lahan KKPA dan kelompok pemuda.

\subsection{Konflik sosial}

Konflik yang terjadi disederhanakan menjadi dua yaitu konflik yang terkait dengan lahan (konflik tenurial) dan konflik non tenurial. Konflik tenurial meliputi konflik tata batas lahan, kepemilikan lahan, penyerobotan lahan, perebutan lahan, jual beli lahan sengketa, tata letak dan distribusi serta rent seeking lahan KKPA, penerbitan SKGR, dan kebakaran lahan. Sementara itu, konflik non tenurial disebabkan karena kebijakan program CSR, kerusakan infrastruktur jalan, pencemaran limbah PKS, pembayaran TBS, dan lainnya

Tabel 4. Pemetaan konflik perkebunan kelapa sawit berdasarkan pola ekspansi

\begin{tabular}{|c|c|c|c|c|}
\hline Pola Ekspansi & Objek Konflik & Jenis Konflik & Tahun Konflik & Keterangan \\
\hline \multirow[t]{3}{*}{ Pola PIR-Trans } & - Tata Batas lahan PT.SBP & Konflik tenurial & $1989-2003$ & \\
\hline & $\begin{array}{l}\text { - Perebutan Areal Pemukiman Eks } \\
\text { SP IV PT.SBP }\end{array}$ & Konflik tenurial & 2004-2012 & \\
\hline & - Konflik jalan & Konflik non tenurial & 2011 & \\
\hline \multirow[t]{6}{*}{ Pola KKPA } & - Tata letak kebun & Konflik tenurial & $2009-2011$ & \\
\hline & - Ganti rugi lahan & Konflik tenurial & 2011-2012 & \\
\hline & - Distribusi lahan & Konflik tenurial & 2010 & Belum terselesaikan \\
\hline & - Penyerahan Lahan & Konflik tenurial & 2010 & Belum terselesaikan \\
\hline & - Tata kelola KKPA & Konflik non tenurial & 2012 & Belum terselesaikan \\
\hline & - Peran Kepala Desa & Konflik non tenurial & 2018 & \\
\hline \multirow[t]{4}{*}{ Pola PKS tanpa kebun } & - Pencemaran limbah & Konflik non tenurial & 2008-2018 & \\
\hline & - Kebakaran lahan & Konflik tenurial & 2018 & \\
\hline & - Pembayaran TBS & Konflik non tenurial & 2016-2018 & \\
\hline & - Penunggakan gaji pagawai & Konflik non tenurial & 2016 & Belum terselesaikan \\
\hline Pola jual beli lahan & - Jual beli lahan bersengketa & Konflik tenurial & 2014 & Belum terselesaikan \\
\hline Pola hibah & - Tata batas & Konflik tenurial & 2015 & \\
\hline Pola mandiri & - Perambahan lahan Perusahaan & Konflik tenurial & 2012 & Belum terselesaikan \\
\hline
\end{tabular}

Tabel 4 menjelaskan bahwa sejak ekpansi perkebunan sawit di Desa terantang Manuk hingga saat ini banyak menimbulkan konflik, konflik tenurial merupak konflik yang sering terjadi, beberapa konflik tenurial berlangsung dengan waktu yang cukup lama, sebagian lagi lagi dapat diselesaikan dengan singkat dengan penyelesaian secara adat.

\subsection{Perubahan Penyelesaian konflik}

Sebelum terjadinya ekspansi perkebunan kelapa sawit masyarakat masih berpegang teguh pada norma adat dalam menyelesaikan konflik yaitu sidang atau musyawarah oleh Ninik Mamak. Dalam penyelesaian konflik pada periode tahun 2010 hingga 2019 sebagian masyarakat masih berpedoman dengan nilai-nilai adat yaitu sidang atau musyarwara oleh Ninik Mamak (Tetua Adat) dalam penyelesaikan konflik, hasil dari sidang adat biasanya berupa hukuman sangsi bagi pihak yang bersalah, sangsi biasanya berupa denda dengan melakukan penyembelihan hewan ternak yaitu dimulai dari sangsi yang paling rendah adalah satu ekor ayam dan paling tinggi adalah satu ekor sapi atau kerbau. Hasil denda tersebut digunakan untuk makan bersama antara pihak yang berkonflik sebagai tanda bahwa konflik tersebut telah berakhir.

Pada periode 2005 pola penyelesaian konflik mengalami perubahan, proses penyelesaian konflik masih dilakukan oleh ninik mamak namun dalam beberapa kasus penyelesaian konflik oleh Ninik Mamak tidak selalu memuaskan keduabelah pihak yang berkonflik sehingga pihak yang merasa tidak puas atas putusan adat melanjutkan konflik tersebut melalui gugatan hukum. Dalam kasus yang berbeda masyarakat sudah tidak lagi menggunakan lembaga adat sebagai sarana penyelesaian konflik melaikan langsung menggunakan jalur hukum untuk menyelesaikan konflik, peran ninik mamak dalam kasus ini hanya menjadi saksi dalam kasus tersebut.

\section{Kesimpulan}

Terdapat 6 pola ekspansi perkebunan kelapa sawit di desa Terantang Manuk. pola PIR-Trans, KKPA, PKS tanpa kebun, jual beli, hibah, dan swadaya atau mandiri. Ekspansi kelapa sawit di Desa Terantang Manuk periode tahun 1990-2019 seluas 3912,9 ha dengan laju ekspansi 134,9 ha/tahun yang mayoritas lahan dikuasai oleh pihak swasta sebesar 83\% 
sedangkan lahan perkebunan smallholder hanya sebesar $17 \%$.

Dampak lingkungan yang ditimbulkan akibat ekspansi sawit adalah menurunkan keragaman buah, ikan, sayur dan hewan buruan. Persepsi masyarakat terhadap ketersediaan air juga mengalami penurunan yang sagnifikan terutama pada musim kemarau.

Dampak ekonomi akibat ekspansi perkebunan kelapa sawit yaitu terjadinya transformasi mata pencaharian rumahtangga petani dari petani ladang, pekebun karet dan nelayan berubah menjadi petani perkebunan kelapa sawit yang kemudian mengakibatkan dominasi persentase nafkahnya dari usaha pertanian kelapa sawit. Besar kecilnya penguasaan lahan sangat berpengaruh terhadapa tingkat kesejahteraan masyarakat.

Dampak sosial akibat ekspansi perkebunan kelapa sawit menyebabkan terjadi konflik dan pergeseran norma adat, nilai kehidupan dan norma dalam penyelesaian konflik.

\section{DAFTAR PUSTAKA}

Amalia R. 2016. Perubahan lanskap ekologi, kerentanan dan resiliensi nafkah rumahtangga petani di sekitar hutan di Kalimantan Timur [tesis]. Bogor [ID]: Institut Pertaian Bogor

Barus B., Shidiq D., Iman LS., Trisasongko BH., Komarsa G., Kusumo R. 2012. Sebaran Kebun Kelapa Sawit Aktual dan Potensi Pengembangannya di Lahan Bergambut di Pulau Sumatra. Prosiding Seminar Nasional: Pengelolaan Gambut Berkelanjutan. Balai Besar Pengembangan dan Penelitian Sumberdaya Lahan Pertanian. Bogor

Creswell, J. W., \& Poth, C. N. (2018). Qualitative Inquiry and Research Design Choosing Among Five Approaches (4th Edition ed.). California: Sage Publishing.

Dewanto F.A., 2013. Melihat jejak perkebunan kelapa sawit di Indonesia. [internet]. Diunduh pada tanggal 15 Desember 2014.

Dhiaulhaq, A., McCarthy, J. F., \& Yasmi, Y. (2018). Resolving industrial plantation conflicts in Indonesia: Can mediation deliver? Forest Policy and Economics, 91, 64-72. https://doi.org/10.1016/j.forpol.2017.12.006

Direktorat Jenderal Perkebunan. (2020). Statistik Perkebunan Indonesia 2018-2020.

Konsorsium Pembaruan Agraria. (2018). Masa Depan Reforma Agraria Melampaui Tahun Politik. In Catatan Akhir Tahun 2018.

Mantiri, M. M. (2013). Analisis Konflik Agraria Di Pedesaan (Suatu Studi Di Desa Lemoh Barat Kecamatan Tombariri). GOVERNANCE, Vol 5, No 1 (2013).

Obidzinski K, Takahashi I, Dermawan A, Komarudin H, Andrianto A. 2013. Can large scale land acquisition for agro-development in Indonesia be managed. Land Use Policy. 30(1):952-965.

Riady, M., \& Bakce, R. (2019). Potensi Konflik Lahan Perkebunan Kelapa Sawit. Lembaga Penelitian Dan Pengabdian Kepada Masyarakat Universitas Riau, Vol 1 (201).

Sadewo, P. A., Darsono, \& Sujarwo. (2014). Dinamika Konflik Agraria Dalam Kehidupan Sosial Masyarakat Sendangayu Dan Surabaya Kecamatan Padangratu. Jurnal Studi Sosial Program Pascasarjana P-IPS, Vol 2, No 4 (2014): Jurnal Studi Sosial.

Sumardjo, Dahri, Riyanto, S., Saleh, A., \& Firmansyah, A. (2014). Tipologi Konflik Berbasis Sumber Daya Pangan Di Wilayah Perkebunan Sawit. Jurnal Ilmu Pertanian Indonesia, Vol. 19 No. 3 (2014): Jurnal Ilmu Pertanian Indonesia, 189-196. doi: 10.1016/j.landusepol.2012.06.018

Thomas, Sikwan, A., \& Rahmaniah, E. (2015). Konflik Sosial Antara Perusahaan Perkebunan Sawit Pt. Borneo Ketapang Permai Dengan Masyarakat Desa Semayang Kecamatan Kembayan, Kabupaten Sanggau. Jurnal Tesis PMIS-UNTAN.

Widiono, S., 2008. Pembangunan perkebunan kelapa sawit serta dampaknya terhadap pelapisan sosial dan strategi nafkah: kasus dua desa Sawah Etnis Serawai dan Jawa di Kabupaten Seluma, Provinsi Bengkulu. Bogor[ID]: Sekolah pascasarjana Institut pertanian Bogor

Wulansari, I. (2017). Indonesia'S Palm Oil Industrialization: The Resistance Of Tanjung Pusaka Villagers, Central Kalimantan Against Palm Oil Industry. Sodality: Jurnal Sosiologi Pedesaan, Vol. 5 No. 1 (2017): Sodality 